\title{
Morpho-anatomical and physiological alterations of passion fruit fertilized with silicon
}

\author{
Bárbara Nogueira Souza Costa(1), Irton de Jesus Silva Costa(1), Gabrielen de Maria Gomes Dias(2), \\ Franscinely Aparecida de Assis ${ }^{(1)}$, Leila Aparecida Salles Pio(1), \\ Joyce Dória Rodrigues Soares ${ }^{(1)}$ and Moacir Pasqual(1)
}

\begin{abstract}
(1)Universidade Federal de Lavras, Departamento de Agricultura, Avenida Doutor Sylvio Menicucci, no 1.001, CEP 37200-000 Lavras, MG, Brazil. E-mail: babinogueiraagro@hotmail.com, jc.agro12@yahoo.com.br, franscinelyagronomia@yahoo.com.br, leila.pio@dag.ufla.br, joyce.soares@dag.ufla.br, mpasqual@dag.ufla.br (2)Universidade da Integração Internacional da Lusofonia Afro-Brasileira, Avenida da Abolição, no 3, Centro, CEP 62790-000 Redenção, CE, Brazil. E-mail: gabriellen@gmail.com
\end{abstract}

\begin{abstract}
The objective of this work was to evaluate the effect of silicon fertilization on gas exchange, leaf anatomy, and ultrastructural characteristics of passion fruit (Passiflora edulis). The treatments comprised four concentrations of silicon $\left(0,0.28,0.55\right.$, and $0.83 \mathrm{~g}$ per pot) at $1 \%$ silicic acid solution $\left(\mathrm{SiO}_{2} \cdot \mathrm{XH}_{2} \mathrm{O}\right)$. This solution was applied around the stems of the plants. The first application was made 15 days after seedlings were transplanted. In total, three applications were made at 15-day intervals. The pots that constituted the control treatment received water in the same amount. After the final application, the plants were subjected to analyses of gas exchange, anatomical changes, and ultrastructural characteristics. The use of silicon promotes anatomical changes in passion fruit seedlings, such as increased adaxial epidermis thickness, reduced palisade parenchyma, and increased polar diameter/equatorial diameter ratio, which is related to stomata functionality. The concentrations of 0.55 and $0.83 \mathrm{~g}$ silicon per pot provide higher rates of photosynthesis, of transpiration, and stomatal conductance. The concentration of $0.83 \mathrm{~g}$ silicon per pot results in the greatest deposition of silicon in the abaxial epidermis of leaf surface.
\end{abstract}

Index terms: Passiflora edulis, photosynthetic rate, silicic acid, ultrastructural features.

\section{Modificações morfoanatômicas e fisiológicas de maracujazeiro fertilizado com silício}

\begin{abstract}
Resumo - O objetivo deste trabalho foi avaliar o efeito da adubação silicatada nas trocas gasosas, na anatomia foliar e nas características ultraestruturais de maracujazeiro (Passiflora edulis). Os tratamentos consistiram em quatro concentrações $(0,0,28,0,55$, e $0,83 \mathrm{~g}$ por vaso) de silício, na forma de solução de ácido silícico $\left(\mathrm{SiO}_{2} \cdot \mathrm{XH}_{2} \mathrm{O}\right)$ a $1 \%$. Esta solução foi aplicada ao redor do caule das plantas. A primeira aplicação foi realizada 15 dias após o transplantio das mudas. No total, foram realizadas três aplicações, em intervalos de 15 dias. Os vasos que constituíram o controle (testemunha) receberam água na mesma quantidade. Após a última aplicação, as plantas foram submetidas a análises de trocas gasosas, alterações anatômicas e características ultraestruturais. O uso de silício promove mudanças anatômicas em mudas de maracujazeiro, como o aumento da espessura da epiderme adaxial, a redução do parênquima paliçádico e a maior relação diâmetro polar/ diâmetro equatorial, que está relacionada à funcionalidade dos estômatos. As concentrações de $0,55 \mathrm{e} 0,83 \mathrm{~g}$ de silício por vaso proporcionam maiores taxas fotossintéticas, de transpiração e de condutância estomática das mudas de maracujazeiro. A concentração de $0,83 \mathrm{~g}$ de silício por vaso proporciona maior deposição de silício na epiderme abaxial da superfície foliar.
\end{abstract}

Termos para indexação: Passiflora edulis, taxa fotossintética, ácido silícico, características ultraestruturais.

\section{Introduction}

The passion fruit occupies a prominent place in fruit growing, even when compared to other tropical fruits with a higher tradition of consumption. Its participation in the horticultural market is guaranteed - it is perfectly adapted to this segment, which values high value-added products (Meletti et al., 2010). The Creative Commons Attribution 4.0 International License national average productivity is $12-15$ tons per hectare, with potential to produce 30-35 tons per hectare (Nogueira Filho et al., 2010). However, this potential is usually not reached due to phytosanitary problems that affect the crop. Therefore, it is necessary to identify techniques that minimize such damages, as the case of silicate fertilization, mainly regarding the production of seedlings. 
The beneficial effects of silicon can be divided into physical and physiological. The physical benefits include accumulation of silicon in the cell walls, which improves the architecture of the plants, reduces water loss through the stomata, and hinders the penetration of pathogens and insects (Botelho et al., 2005). The physiological benefits are little studied, but many studies report that silicon may favor the increase in the photosynthetic rate (Ferraz et al., 2014), photosynthetic pigment contents (Ávila et al., 2010), and productivity (Paulino et al., 2013).

It is known that the leaf is an organ with high plasticity. Improvement in the interception of light can influence the anatomy of the leaf. Studies show that the application of silicon leads to changes in the leaf anatomy of several species such as orchids (Soares et al., 2012), strawberry (Braga et al., 2009), and coffee (Botelho et al., 2009). Other studies report the efficiency of silicon in the increase in the photosynthetic rate. Furthermore, the positive effect of silicon on the anatomy of anthurium (Dias et al., 2014) and banana (Luz et al., 2012) has been demonstrated.

The objective of this work was to evaluate the effect of silicon fertilization on gas exchange, leaf anatomy, and ultrastructural characteristics of passion fruit.

\section{Materials and Methods}

Passion fruit seeds (Passiflora edulis Sims) were sown in polystyrene trays containing Tropstrato substrate, in which they remained for 60 days. The seedlings, approximately $15 \mathrm{~cm}$ tall, were transplanted to polyethylene pots containing $1.1 \mathrm{~kg}$ of Tropstrato substrate and arranged randomly on the bench where they were irrigated daily. There was no additional fertilization. Treatments consisted of concentrations of silicon $0,0.28,0.55$, and $0.83 \mathrm{~g}$ per pot in the form of silicic acid solution $\left(\mathrm{SiO}_{2} \cdot \mathrm{XH}_{2} \mathrm{O}\right)$ at $1 \%$ (Pereira et al., 2010).

This solution was applied around the stem of the plants (drench). The first application was performed 15 days after transplant. In total, three applications were conducted at 15 day-intervals. The control vases received water in the same amount. After the final application, analyses of gas exchange, anatomical changes, and ultrastructural characteristics of plants were performed.
The gas exchange - photosynthetic rate (A), internal carbon (Ci), transpiration (E), stomatal conductance (Gs), and relation internal carbon/external carbon $(\mathrm{Ci} / \mathrm{Ca})$ - was evaluated using an infrared gas exchange analyzer (IRGA, model LI-6400, LI-COR, Nebraska, USA). To evaluate these variables, fully expanded leaves were selected on six plants per treatment, starting at 8:00 a.m. The photosynthetically active photon flux density was set in the equipment chamber at $1,000 \mu \mathrm{mol} \mathrm{m} \mathrm{m}^{-2} \mathrm{~s}^{-1}$.

Samples from the middle third of the second fully expanded leaf were collected from 4 different plants per treatment and previously fixed in FAA $(70 \%$ formaldehyde - glacial acetic acid -, 70\% ethanol) for 72 hours, and subsequently stored in $70 \%$ ethanol (v/v) for the anatomical analyses (Johansen, 1940). The cross sections were obtained with an LPC table microtome and paradermal sections by hand using a steel blade. The sections underwent clarification with sodium hypochlorite (1-1.25\% active chlorine), triple washing in distilled water, and staining with either safrablau solution $(0.1 \%$ astra blue and $1 \%$ safranin) for the cross sections or $1 \%$ safranin for the paradermal sections. The materials were subsequently mounted on semipermanent slides with glycerinated water following the methodology described by Kraus \& Arduin (1997). The slides were observed and photographed under an Olympus BX 60 optical microscope coupled to a Canon A630 digital camera. The images were analyzed in UTHSCSA Image J image analyzing software (Schneider et al., 2012) with 6 replicates for each variable analyzed. The thickness of the epidermis of the adaxial and abaxial face, mesophyll, main nervure, and palisade and spongy parenchyma were measured. For the characterization of the stomata, analysis was performed on the stomatal density (number of stomata per $\mathrm{mm}^{2}$ ), polar diameter (PD), equatorial diameter (ED) and the $\mathrm{PD} / \mathrm{ED}$ ratio obtained in Olympus CBB and Ken-a-vision 2100 microscopes.

Samples of the middle third of 4 leaves were fixed in Karnovsky solution (Karnovsky, 1965), post-fixed in osmium tetroxide $\left(\mathrm{OsO}_{4}\right)$, and dehydrated in increasing solutions of acetone $(30,50,70,90$, and $100 \%)$ for the ultrastructural characteristics analyses. Thereafter, they were subjected to critical point drying, using liquid $\mathrm{CO}_{2}$ as a transition liquid (Robards, 1978). They were later covered with gold $(20 \mathrm{~nm})$, and analyzed by 
scanning electron microscopy LEO-EVO (Carl Zeiss, Germany) following the Alves (2004) protocol.

The design was completely randomized with 4 treatments and 20 repetitions per treatment. All data were submitted to analysis of variance using the SISVAR statistical program (Ferreira, 2011), data regression, or the Scott-Knott test.

\section{Results and Discussion}

There were significant differences between treatment groups in photosynthetic rate, transpiration, and stomatal conductance (Table 1). Silicon concentrations of $0.28,0.55$, and $0.83 \mathrm{~g}$ per pot showed higher photosynthetic rate and transpiration compared to the control. It is known that silicon fertilization leads to better plant architecture due to morphological and physiological adaptations, leading to more upright leaves and more efficient light interception, which is reflected in the increased photosynthetic rate (Deren et al., 1994). The increase in plant transpiration may have occurred because the stomatal opening is directly linked to photosynthetic rate and transpiration. At the same time, the plant absorbs $\mathrm{CO}_{2}$ for photosynthesis; thereby, it loses water to the atmosphere in the transpiration process (Pinto et al., 2012).

The concentration of $0.28 \mathrm{~g}$ per pot increased the net photosynthetic rate by $48.82 \%$ compared to the control, followed by the concentrations of 0.55 and 0.83 g per pot, which increased the rate by $43.25 \%$ and $39.30 \%$, respectively. Pinto et al. (2012) investigated the influence of silicon on Theobroma cacao, and observed an increase in the net photosynthetic rate. The authors observed that regardless of the genotype, the concentration of $3 \mathrm{~mL} \mathrm{~L}^{-1}$ increased the net photosynthesis rate by $44 \%$, compared to the control, followed by the $6 \mathrm{~mL} \mathrm{~L}^{-1}$ concentration, with $14 \%$. Other experiments have also shown the beneficial effect of silicon on photosynthesis in Glycine max (Shen et al., 2010), Musa spp. (Luz et al., 2012), Theobroma cacao (Zanetti et al., 2016), and Anthurium cv. Rubi (Dias et al., 2014).

For internal carbon $(\mathrm{Ci})$ and the ratio of internal and external carbon $(\mathrm{Ci} / \mathrm{Ca})$, there was no statistical difference between treatments (Table 1). Pinto et al. (2012) studied the influence of silicon on cocoa, and also found no significant differences in internal carbon concentration (Ci). According to Table 1, the concentrations of 0.55 and $0.83 \mathrm{~g}$ per pot led to higher stomatal conductance when compared to the $0.28 \mathrm{~g}$ per pot concentration and control treatment, but the concentration $0.28 \mathrm{~g}$ per pot led to greater stomatal conductance when compared to control.

According to Paiva et al. (2005), stomatal conductance regulates gas exchange and, therefore, has a direct relationship with the photosynthetic process and the consequent growth and development of plants. The results of the present study show the direct relationship between stomatal conductance and photosynthesis. The treatments that resulted in the highest photosynthetic rate also had the highest stomatal conductance. These results also show the influence of silicon on gas exchange, since this element led to an increase in most of the analyzed variables.

There was no significant difference between treatments for anatomical characteristics, mesophyll, spongy parenchyma, main nervure and abaxial epidermis. As for the characteristics equatorial diameter, stomata polar diameter and PD/ED ratio, there was significant difference between treatments (Table 2).

Table 1. Photosynthetic rate (A), internal carbon (Ci), transpiration (E), stomatal conductance (Gs), and relation internal carbon/external carbon $(\mathrm{Ci} / \mathrm{Ca})$ for passion fruit (Passiflora edulis) seedling leaves submitted to different silicon concentrations $^{(1)}$.

\begin{tabular}{|c|c|c|c|c|c|}
\hline $\begin{array}{l}\text { Silicon } \\
(\text { g per pot })^{(2)}\end{array}$ & $\begin{array}{c}\mathrm{A} \\
\left(\mu \mathrm{mol} \mathrm{m} \mathrm{m}^{-2} \mathrm{~s}^{-1}\right)\end{array}$ & $\begin{array}{c}\mathrm{Ci} \\
(\mathrm{mol})\end{array}$ & $\begin{array}{c}\mathrm{E} \\
(\mu \mathrm{mol})\end{array}$ & $\begin{array}{c}\text { Gs } \\
\left(\mu \mathrm{mol} \mathrm{m} \mathrm{m}^{-2} \mathrm{~s}^{-1}\right)\end{array}$ & $\mathrm{Ci} / \mathrm{Ca}$ \\
\hline 0 & $1.4114 \mathrm{~b}$ & $158.9232 \mathrm{a}$ & $0.0002 \mathrm{~b}$ & $0.0106 \mathrm{c}$ & $0.4055 \mathrm{a}$ \\
\hline 28 & $4.5701 \mathrm{a}$ & $174.5083 \mathrm{a}$ & $0.0006 a$ & $0.0194 b$ & $0.4457 \mathrm{a}$ \\
\hline 55 & $4.8599 \mathrm{a}$ & $179.9594 a$ & $0.0006 a$ & $0.0274 \mathrm{a}$ & $0.4563 \mathrm{a}$ \\
\hline 83 & $5.4018 \mathrm{a}$ & $181.8707 \mathrm{a}$ & $0.0007 \mathrm{a}$ & $0.0313 \mathrm{a}$ & $0.4641 \mathrm{a}$ \\
\hline $\mathrm{CV}^{(3)}(\%)$ & 14.34 & 16.44 & 25.97 & 14.75 & 16.91 \\
\hline
\end{tabular}

${ }^{(1)}$ Means followed by equal letters do not differ by the Scott-Knott test at $5 \%$ probability. ${ }^{(2)}$ Silicic acid. ${ }^{(3)}$ Coefficient of variation. 
Concentrations 0.0 (control) and $0.28 \mathrm{~g}$ per pot showed stomata with greater equatorial diameter in relation to the other treatments. The 0.0 (control), 0.28 , and $0.55 \mathrm{~g}$ per pot concentrations showed stomata with higher polar diameter in relation to the $0.83 \mathrm{~g}$ per pot concentration. The concentrations $0.28,0.55$, and $0.83 \mathrm{~g}$ per pot showed higher $\mathrm{PD} / \mathrm{ED}$ compared to the control (Table 2).

Khan et al. (2002) reported that the polar and equatorial diameter ratio (DP/DE) is associated with guard cells and that it constitutes an important characteristic feature of the stomata. An elliptical shape (higher DP/DE) is characteristic of more functional stomata. Alternatively, a rounded shape (smaller DP/DE) is associated with stomata that do not have appropriate function. However, the type and condition of cultivation may modify these results. Elliptical stomata may lead to a higher $\mathrm{CO}_{2}$ uptake, causing higher photosynthetic potential and reduced transpiration rate (Castro et al., 2009). Thus, in the present study, the stomata may be more functional in the presence of silicon. This is important because the plants, in the presence of silicon, have higher photosynthetic rates in relation to the control.

Rossatto et al. (2009) also showed that variations in the size and frequency of stomata indicate the ability of plants to rearrange these structures of the epidermis in response to environmental modifications, causing a greater contribution of the stomata to photosynthetic rate and transpiration, in an adequate manner.

A decrease in stomatal density was observed (Figure $1 \mathrm{~A}$ ), reaching the minimum of 43.68 at the concentration of 0.50 gram of silicon per pot. Although this decrease in stomatal density has been previously reported, it indicates that it is not the quantity that is important, but the quality of these stomata. Thus, despite the low number of stomata, the silicon concentrations led to increased function of stomatal passion fruit plants compared to the control treatment.

Similarly, there was a decrease in the thickness of the palisade parenchyma until a minimum of $64.84 \mu \mathrm{m}$, corresponding to a concentration of $0.51 \mathrm{~g}$ per pot (Figure $1 \mathrm{~B}$ ). There was an increase in the thickness of the adaxial epidermis to a maximum of $61.21 \mu \mathrm{m}$, corresponding to a concentration of $0.50 \mathrm{~g}$ per pot (Figure $1 \mathrm{C}$ ).

Braga et al. (2009) used silicon sources in vitro, such as potassium silicate or calcium silicate and sodium silicate, in their study on strawberry seedlings, and observed that silicon favored an increase in the thickness of the palisade parenchyma in the seedlings obtained by micropropagation. These results were not consistent with those of the present study.

Zanetti et al. (2016) found no difference in the thickness of palisade parenchyma in cacao plants fertilized with different concentrations of silicon. The results obtained with regard to the thickness of the palisade parenchyma were similar to those obtained by Luz et al. (2012), in which the use of the sodium silicate source in vitro led to lower thickness of this tissue in relation to the control in banana seedlings obtained by micropropagation.

Thus, the behavior of silicon can vary according to the species and cultivation environment. In most species studied, silicon causes a positive effect on plant characteristics. However, in some species, this element may be responsible for promoting some anatomical changes.

In the present study, silicon led to an increase in the thickness of the adaxial epidermis. Epstein (2001)

Table 2. Anatomical characteristics of passion fruit (Passiflora edulis) leaves submitted to different silicon concentrations: mesophyll, spongy parenchyma (SP), main nervure (MN), abaxial epidermis (ABE), stomata equatorial diameter (SED), stomata polar diameter (SPD), and ratio SPD/SED(1).

\begin{tabular}{|c|c|c|c|c|c|c|c|}
\hline $\begin{array}{l}\text { Silicon } \\
(\mathrm{g} \text { per pot })^{(2)}\end{array}$ & $\begin{array}{c}\text { Mesophyll } \\
(\mu \mathrm{m})\end{array}$ & $\begin{array}{c}\mathrm{SP} \\
(\mu \mathrm{m})\end{array}$ & $\begin{array}{c}\mathrm{MN} \\
(\mu \mathrm{m})\end{array}$ & $\begin{array}{l}\mathrm{ABE} \\
(\mu \mathrm{m})\end{array}$ & $\begin{array}{l}\text { SED } \\
(\mu \mathrm{m})\end{array}$ & $\begin{array}{l}\text { SPD } \\
(\mu \mathrm{m})\end{array}$ & $\begin{array}{l}\mathrm{SPD} / \\
\mathrm{SED}\end{array}$ \\
\hline 0.0 & $319.04 \mathrm{a}$ & $166.07 \mathrm{a}$ & $587.60 \mathrm{a}$ & $47.14 \mathrm{a}$ & $28.09 \mathrm{a}$ & $38.92 \mathrm{a}$ & $1.38 \mathrm{~b}$ \\
\hline 0.28 & $318.91 \mathrm{a}$ & $146.31 \mathrm{a}$ & $580.09 \mathrm{a}$ & $46.27 \mathrm{a}$ & $27.41 \mathrm{a}$ & $39.03 a$ & $1.43 \mathrm{a}$ \\
\hline 0.55 & $302.77 \mathrm{a}$ & $126.92 \mathrm{a}$ & $652.60 \mathrm{a}$ & $45.81 \mathrm{a}$ & $24.94 b$ & $37.39 a$ & $1.50 \mathrm{a}$ \\
\hline 0.83 & $336.20 \mathrm{a}$ & $161.25 \mathrm{a}$ & $628.35 \mathrm{a}$ & $50.69 a$ & $24.37 b$ & $34.73 b$ & $1.43 \mathrm{a}$ \\
\hline $\mathrm{CV}^{(3)}(\%)$ & 13.90 & 25.74 & 9.70 & 11.12 & 6.65 & 5.86 & 7.32 \\
\hline
\end{tabular}

${ }^{(1)}$ Means followed by equal letters do not differ by the Scott-Knott test at $5 \%$ probability. ${ }^{(2)}$ Silicic acid. CV, coefficient of variation. 

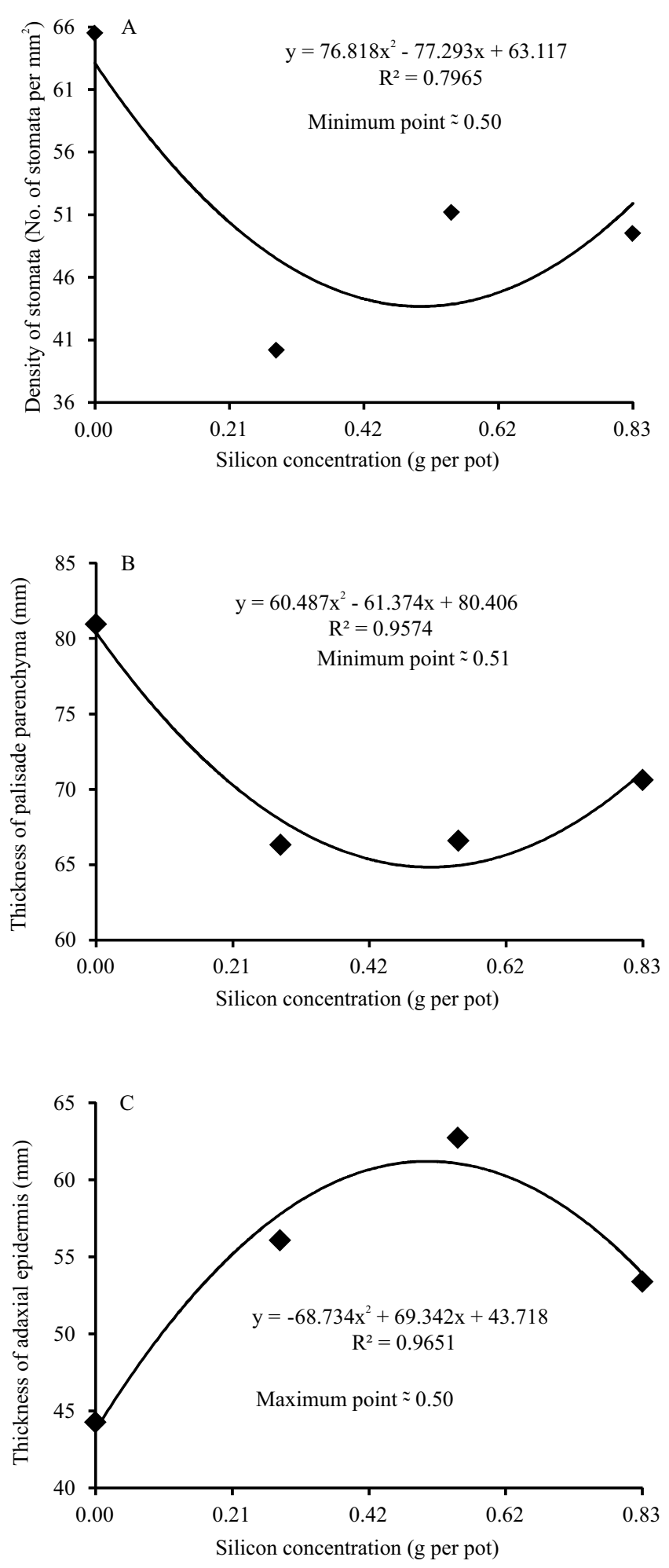

Figure 1. Density of stomata (A), thickness of palisade parenchyma (B), and thickness of adaxial epidermis (C) of passion fruit (Passiflora edulis) leaves subjected to different silicon (silicic acid) concentrations. showed that, when accumulated by plants, silicon causes anatomical changes in their tissues, such as the appearance of thicker epidermal cells due to the deposition of silicon.

Some authors have reported an increase in the epidermis due to the application of silicon in some species such as banana (Luz et al., 2012), strawberry (Braga et al., 2009), and orchid (Soares et al., 2012).

With respect to characterization of the tissues, in all treatments it was observed that passion fruit leaves have an unstratified epidermis. The dorsiventral mesophyll has a layer of palisade cells, occupying approximately one third of the thickness of the mesophyll. The spongy parenchyma consists of six to seven layers, with the presence of braciform cells and convex main nervure, in accordance with Beraldo \& Kato (2010) (Figure 2).

In relation to the stomata, they are classified as anomocytic stomata because they are bordered by two or four subsidiary cells. The stomata are distributed on the surface of the abaxial epidermis, and the leaves are classified as the hypostomatic type (Beraldo \& Kato, 2010) (Figure 3).

By means of scanning electron microscopy (SEM), a more significant deposition of epicuticular wax on the abaxial epidermal surface of passion fruit subjected to treatment with silicon was observed when compared to the control (Figure 4).

Polymerization of silicon, called the silicification process, on the lower surface of the leaf is common in grasses (Lux et al., 2002) and can occur in dicotyledonous plants, such as coffee (Pozza et al., 2004). According to Pozza et al. (2004), this occurs due to the increase in the cuticle in the lower surface of leaves treated with silicon. This increase is mainly due to the more developed epicuticular wax layer. These authors concluded that this process is important to prevent the viral pathogenesis processes, such as the germination and penetration of fungi, and to facilitate the accumulation of antifungal substances in the cuticle.

In view of the above, silicon, although not an essential element, should be considered a beneficial element as it contributes to the improvement in the anatomical and physiological attributes of passion fruit seedlings. Treatments that allow changes in plant morphology and physiology are extremely important, especially in the initial phase of seedling production, because when they are brought to the field, they will be much better 


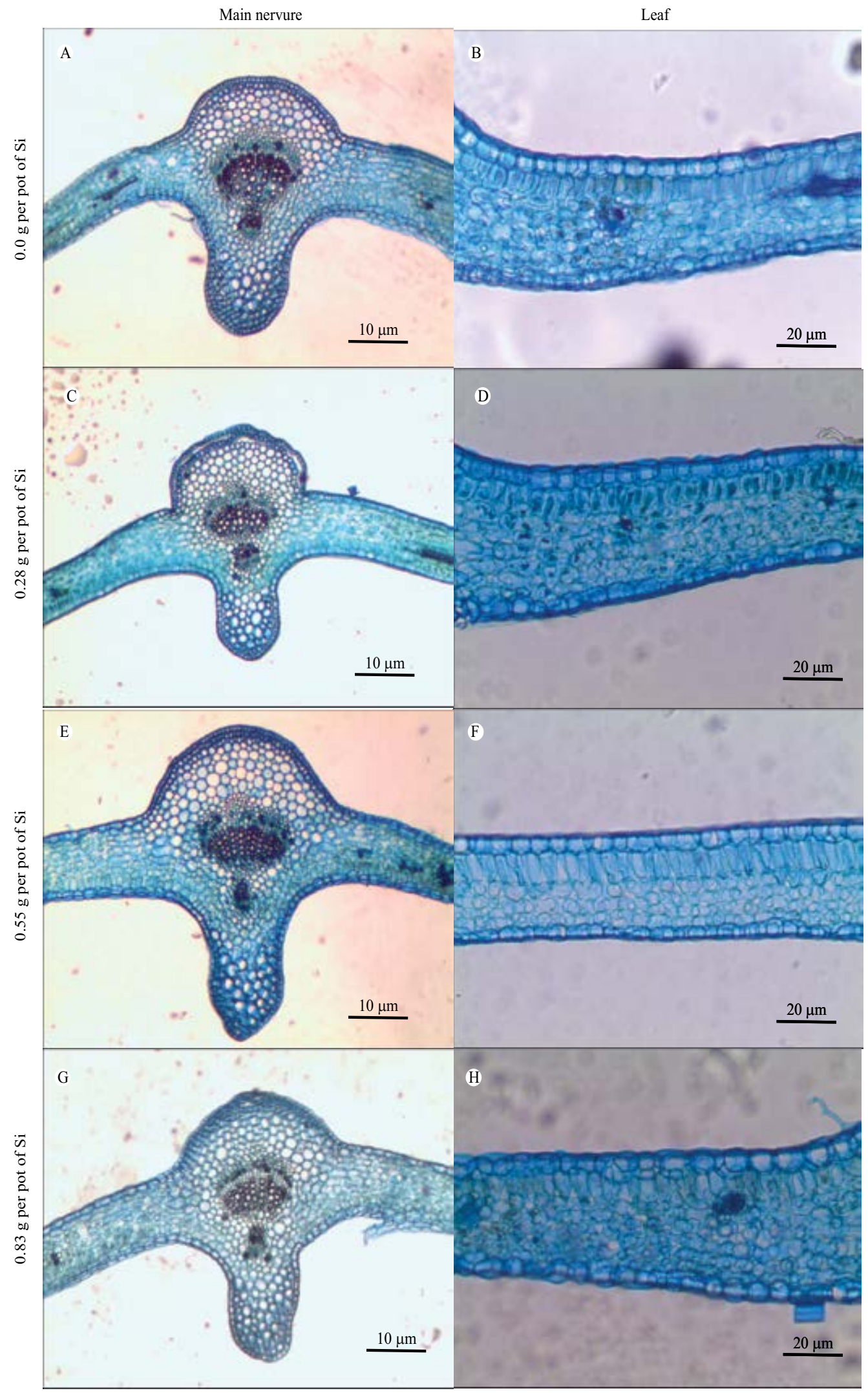

Figure 2. Photomicrographs of cross sections of Passiflora edulis main nervure and leaf, subjected to different silicon (silicic acid) concentrations. 

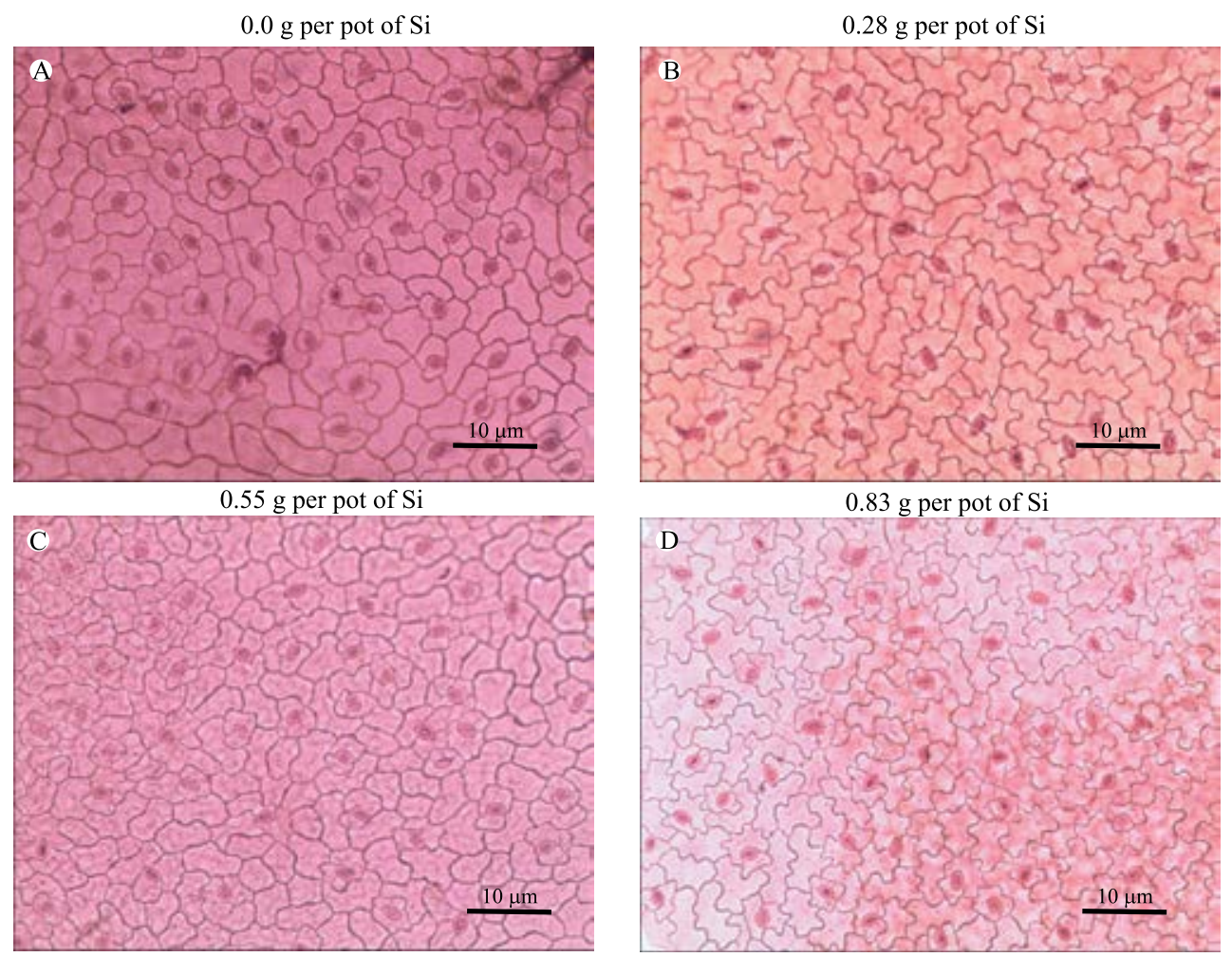

Figure 3. Photomicrographs of paradermal sections showing stomata in abaxial face of Passiflora edulis leaves, subjected to different silicon (silicic acid) concentrations.
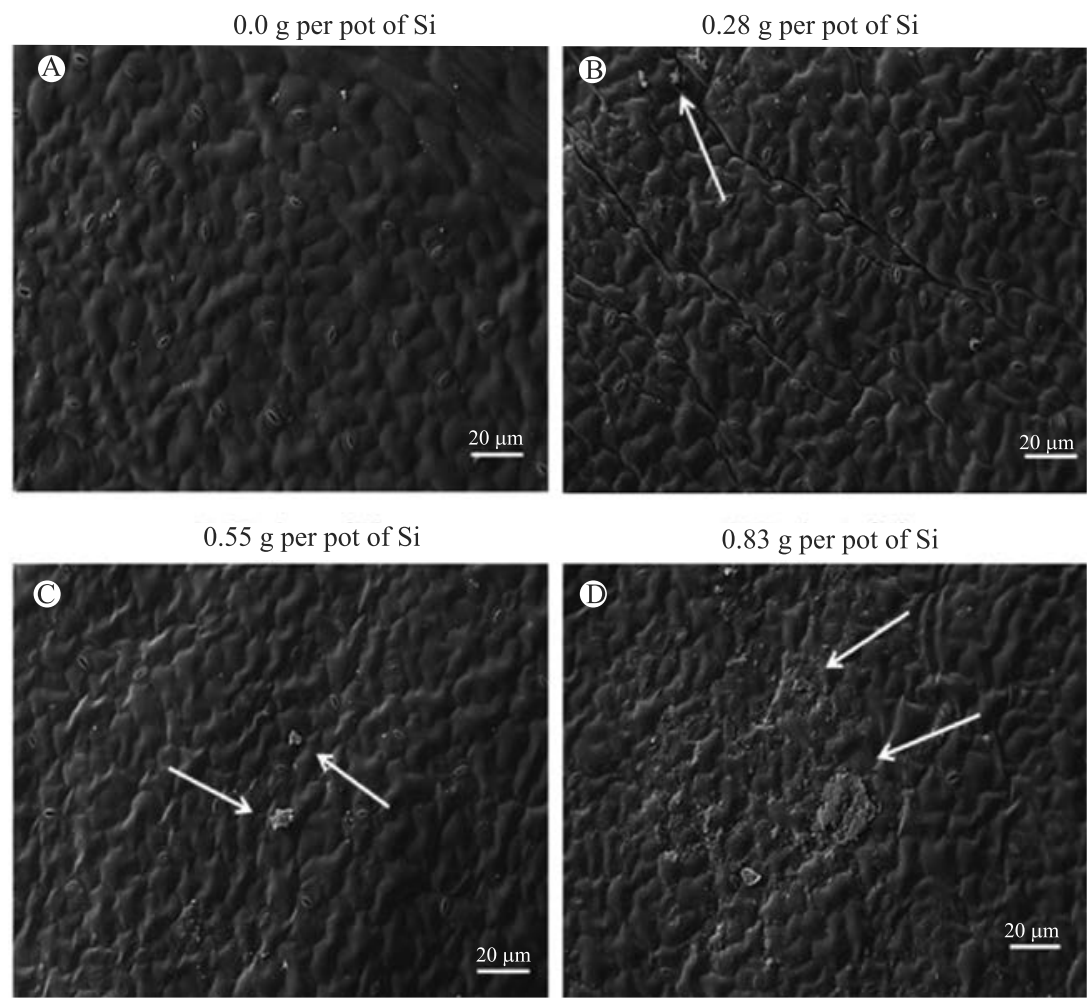

Figure 4. Electron micrographs of paradermal sections showing the abaxial stomata of Passiflora edulis with deposition of epicuticular wax (arrows). Leaves were subjected to different silicon (silicic acid) concentrations. 
adapted to the abiotic and biotic stresses in the field, culminating in higher yields of this culture.

\section{Conclusions}

1. Silicon fertilization promotes anatomical changes in passion fruit seedlings, including an increase in adaxial epidermis thickness, a reduction in palisade parenchyma, and an increase in the PD/ED ratio, which is related to stomata functionality.

2. The concentrations 0.55 and $0.83 \mathrm{~g}$ of silicon per pot lead to higher photosynthetic rates, transpiration, and stomatal conductance of passion fruit seedlings.

3. The concentration $0.83 \mathrm{~g}$ of silicon per pot leads to greater deposition of silicon in the abaxial epidermis leaf surface.

\section{Acknowledgments}

To the Conselho Nacional de Desenvolvimento Científico e Tecnológico (CNPq), for financial support and fellowships; and to the Laboratório de Microscopia Eletrônica of Universidade Federal de Lavras, for support.

\section{References}

ALVES, E. Introdução à microscopia eletrônica. Lavras: Ed. da Ufla: Faepe, 2004. 88p.

ÁVILA, F.W.; BALIZA, D.P.; FAQUIN, V.; ARAÚJO, J.L.; RAMOS, S.J. Interação entre silício e nitrogênio em arroz cultivado sob solução nutritiva. Revista Ciência Agronômica, v.41, p.184-190, 2010. DOI: 10.1590/S1806-66902010000200003.

BERALDO, J.; KATO, E.T.M. Morfoanatomia de folhas e caules de Passiflora edulis Sims, Passifloraceae. Revista Brasileira de Farmacognosia, v.20, p.233-239, 2010. DOI: 10.1590/S0102695X2010000200016.

BOTELHO, D.M. dos S.; POZZA, E.A.; ALVES, E.; FURTINI NETO, A.E.; BARBOSA, J.P.R.A.D.; CASTRO, D.M. Aspectos anatômicos e fisiológicos de mudas de cafeeiro (Coffea arabica L.) com cercosporiose (Cercospora coffeicola Berk. \& Cook.) adubadas com ácido silícico. Coffee Science, v.4, p.93-99, 2009.

BOTELHO, D.M.S.; POZZA, E.A.; POZZA, A.A.A.; CARVALHO, J.D. de; BOTELHO, C.E.; SOUZA, P.E. de. Intensidade da cercosporiose em mudas de cafeeiro em função de fontes e doses de silício. Fitopatologia Brasileira, v.30, p.582588, 2005. DOI: 10.1590/S0100-41582005000600003.

BRAGA, F.T.; NUNES, C.F.; FAVERO, A.C.; PASQUAL, M.; CARVALHO, J.G. de; CASTRO, E.M. de. Características anatômicas de mudas de morangueiro micropropagadas com diferentes fontes de silício. Pesquisa Agropecuária Brasileira, v.44, p.128-132, 2009. DOI: 10.1590/S0100-204X2009000200003.

CASTRO, E.M. de; PEREIRA, F.J.; PAIVA, R. Histologia vegetal: estrutura e função de órgãos vegetativos. Lavras: Ed. da Ufla, 2009. 234p.

DEREN, C.W.; DATNOFF, L.E.; SNYDER, G.H.; MARTIN, F.G. Silicon concentration, disease response, and yield components of rice genotypes grown on flooded organic histosols. Crop Science, v.34, p.733-737, 1994. DOI: 10.2135/ cropsci1994.0011183X003400030024x.

DIAS, G. de M.G.; SOARES, J.D.R.; PASQUAL, M.; SILVA, R.A.L.; RODRIGUES, L.C. de A.; PEREIRA, F.J.; CASTRO, E.M. de. Photosynthesis and leaf anatomy of Anthurium cv. Rubi plantlets cultured in vitro under different silicon ( $\mathrm{Si}$ ) concentrations. Australian Journal of Crop Science, v.8, p.11601167, 2014.

EPSTEIN, E. Silicon in plants: facts vs. concepts. Studies in Plant Science, v.8, p.1-15, 2001. DOI: 10.1016/S0928-3420(01)80005-7.

FERRAZ, R.L. de S.; BELTRÃO, N.E. de M.; MELO, A.S. de; MAGALHÃES, I.D.; FERNANDES, P.D.; ROCHA, M. do S. Trocas gasosas e eficiência fotoquímica de cultivares de algodoeiro herbáceo sob aplicação de silício foliar. Semina: Ciências Agrárias, v.35, p.735-748, 2014. DOI: 10.5433/1679-0359.2014v3 $5 \mathrm{n} 2 \mathrm{p} 735$.

FERREIRA, D.F. Sisvar: a computer statistical analysis system. Ciência e Agrotecnologia, v.35, p.1039-1042, 2011. DOI: 10.1590/ S1413-70542011000600001.

JOHANSEN, D.A. Plant microtechnique. New York: McGraw Hill, 1940. 523p.

KARNOVSKY, M. J. A formaldehyde-glutaraldehyde fixative of high osmolality for use in electron microscopy. The Journal of Cell Biology, v.27, p.137-138, 1965.

KHAN, P.S.S.V.; KOZAI, T.; NGUYEN, Q.T.; KUBOTA, C.; DHAWAN, V. Growth and net photosynthetic rates of Eucalyptus tereticornis Smith under photomixotrophic and various photoautotrophic micropropagation conditions. Plant Cell, Tissue and Organ Culture, v.71, p.141-146, 2002. DOI: 10.1023/A:1019935208418.

KRAUS, J.E.; ARDUIN, M. Manual básico de métodos em morfologia vegetal. Seropédica: Ed. da UFRRJ, 1997. p.198.

LUX, A.; LUXOVÁ, M.; HATTORI, T.; INANAGA, S.; SUGIMOTO, Y. Silicification in sorghum (Sorghum bicolor) cultivars with different drought tolerance. Physiologic Plantarum, v.115, p.87-92, 2002. DOI: 10.1034/j.1399-3054.2002.1150110.x.

LUZ, J.M.Q.; ASMAR, S.A.; PASQUAL, M.; ARAUJO, A.G. de; PIO, L.A.S.; RESENDE, R.F. Modifications in leaf anatomy of banana plants cultivar 'Maçã' subjected to different silicon sources in vitro. Acta Horticulturae, v.1, p.239-244, 2012. DOI: 10.17660/ActaHortic.2012.961.30.

MELETTI, L.M.M.; OLIVEIRA, J.C. de; RUGGEIRO, C. Maracujá. Jaboticabal: Funep, 2010. 55p. (Frutas nativas, 6).

NOGUEIRA FILHO, G.C.; RONCATTO, G.; RUGGIERO, C.; OLIVEIRA, J.C. de; MALHEIROS, E.B.; DAMIÃO FILHO, 
C.F. Aspectos histológicos da união da enxertia hipocotiledonar do maracujazeiro-amarelo. Revista Brasileira de Fruticultura, v.32, p.515-521, 2010. DOI: 10.1590/S0100-29452010005000068.

PAIVA, A.S.; FERNANDES, E.J.; RODRIGUES, T.J.D.; TURCO, J.E.P. Condutância estomática em folhas de feijoeiro submetido a diferentes regimes de irrigação. Engenharia Agrícola, v.25, p.161-169, 2005. DOI: 10.1590/S0100-69162005000100018.

PAULINO, A. da S.; ALBUQUERQUE, A.W.; MOURA FILHO, G.; PEREIRA, F.R. da S. Helicônia “Golden Torch": produtividade e qualidade pós-colheita sob diferentes fontes e doses de silício. Revista Brasileira de Engenharia Agrícola e Ambiental, v.17, p.615-621, 2013. DOI: 10.1590/S1415-43662013000600007.

PEREIRA, R.R.C.; MORAES, J.C.; PRADO, E.; DA COSTA, R.R. Resistance inducing agents on the biology and probing behaviour of the greenbug in wheat. Scientia Agricola, v.67, p.430-434, 2010. DOI: 10.1590/S0103-90162010000400009.

PINTO, D.G.; AGUILAR, M.A.G.; SOUZA, C.A.S.; SILVA, D.M.; SIQUEIRA, P.R.; CAO, J.R.; ZANETTI, L.V. Alterações fisiológicas após aplicação de silício em cacau e sua influência na preferência por pulgões. Revista Ceres, v.59, p.360-367, 2012. DOI: $10.1590 / \mathrm{S} 0034-737 X 2012000300010$.

POZZA, A.A.; ALVES, E.; POZZA, E.A.; CARVALHO, J.G. de; MONTANARI, M.; GUIMARÃES, P.T.G.; SANTOS, D.M. Efeito do silício no controle da cercosporiose em três variedades de cafeeiro. Fitopatologia Brasileira, v.29, p.185-188, 2004. DOI: 10.1590/S0100-41582004000200010.
ROBARDS, A.W. An introduction to techniques for scanning electron microscopy of plant cells. In: HALL, J.L. (Ed.). Electron microscopy and cytochemistry of plant cells. New York: Elsevier, 1978. p.343-444.

ROSSATTO, D.R.; HOFFMANN, W.A.; FRANCO, A.C. Características estomáticas de pares congenéricos de cerrado e mata de galeria crescendo numa região transicional no Brasil central. Acta Botanica Brasilica, v.23, p.499-508, 2009. DOI: 10.1590/S0102-33062009000200021.

SCHNEIDER, C.A.; RASBAND, W.S.; ELICEIRI, K.W. NIH Image to ImageJ: 25 years of image analysis. Nature methods, v.9, p.671-675, 2012. DOI: 10.1038/nmeth.2089.

SHEN, X.; ZHOU, Y.; DUAN, L.; LI, Z.; ENEJI, A.E.; LI, J. Silicon effects on photosynthesis and antioxidant parameters of soybean seedlings under drought and ultraviolet-B radiation. Journal of Plant Physiology, v.167, p.1248-1252, 2010. DOI: 10.1016/j.jplph.2010.04.011.

SOARES, J.D.R.; PASQUAL, M.; ARAUJO, A.G. de; CASTRO, E.M. de; PEREIRA, F.J.; BRAGA, F.T. Leaf anatomy of orchids micropropagated with different silicon concentrations. Acta Scientiarum. Agronomy, v.34, p.413-421, 2012. DOI: 10.4025/ actasciagron.v34i4.15062.

ZANETTI, L.V.; MILANEZ, C.R.D.; GAMA, V.N.; AGUILAR, M.A.G.; SOUZA, C.A.S.; CAMPOSTRINI, E.; FERRAZ, T.M.; FIGUEIREDO, F.A.M.M. de A. Leaf application of silicon in young cacao plants subjected to water deficit. Pesquisa Agropecuária Brasileira, v.51, p.215-223, 2016. DOI: 10.1590/ S0100-204X2016000300003.

$\overline{\text { Received on February 10, } 2017 \text { and accepted on June 14, } 2017}$ 